\title{
PROGRAM PENGEMBANGAN POTENSI DAN PEMBERDAYAAN MELALUI PENDIDIKAN LIFE SKILL," (PENGEMBANGAN LIFE SKILL PENGHUNI PANTI ASUHAN AT-TAQWA MUHAMMADIYAH KENAGARIAN III KOTO KEC. RAMBATAN KABUPATEN TANAH DATAR)
}

\begin{abstract}
Irwandi
Jurusan Komunikasi dan Penyiaran Islam, Fakultas Ushuluddin Adab dan Dakwah, IAIN Batusangkar
\end{abstract} Korespondensi: Jl Sudirman No. 137 Kuburajo, Limakaum, Batusangkar, Sumatera Barat, Indonesia

\begin{abstract}
Orphans in Islam have a specific position in Islam as contextually religious already exists in the Letter Alma'un verses 1-7, in this context we are expected to be able to empower orphans especially to develop themselves thoroughly and specifically which leads to the development of life skills intended for self-development so that it can be useful for themselves, society and nation and religion. Methods of self-development Through education, it forms the character of children and understands their nature, the essence of their lives, the nature of community, religion and state. Seeing such conditions, the orphanage plays an important role in educating foster children in the form of safe skills to minimize the condition of children who are unable to continue their education, At-Taqwa Muhammadiyah Orphanage Nagari III Koto is one of the orphanages registered in the Social Service and the Tanah Datar district labor force with a total of 56 foster children with a total of 3 caregivers, is a valuable asset in fostering life that leads to education patterns that are oriented towards the lifeskill. The method used in this study is a descriptive method with a qualitative approach, with the focus of the discussion is the Potential and Empowerment Development Program through Life Skill Education at the orphanage At-taqwa Muhammadiyah kenagarian III koto Kec. Rambat Tanah Datar Regency.
\end{abstract}

Keywords: Orphanage and Life Skill

\section{PEDAHULUAN}

Pemberdayaan anak Yatim dalam Islam merupakan salah satu syarat mutlak dalam dalam menuju manusia yang sempurna di sisi Allah SWT. Sesuai dengan firman Allah SWT dalam surat AlMa'un ayat 1-7:

$$
\text { أَرَ }
$$

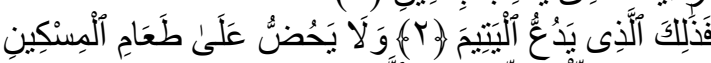

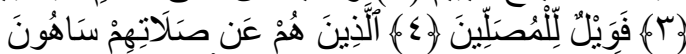

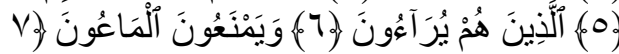

Artinya:

1). Tahukah kamu (orang) yang mendustakan agama?
2). Itulah orang yang menghardik anak yatim

3). Dan tidak menganjurkan memberi makan orang miskin

4). Maka kecelakaanlah bagi orangorang yang shalat

5). (yaitu) orang-orang yang lalai dari shalatnya

6). Orang-orang yang berbuat riya

7). Dan enggan (menolong dengan) barang berguna

Secara ideologis dinyatakan bahwa fakir miskin dan anak-anak terlantar dipelihara oleh Negara (UUD 1945 Pasal 
34) hal ini tentunya mengimplikasikan pada usaha kemanusiaan terhadap anakanak yang terlahir dalam kondisi memprihatinkan agar mendapatkan perawatan dan pemeliharaan yang mencukupi dalam semua aspek kehidupannya. Tentu saja hal ini menjadi tanggung jawab dan tugas dari penyelenggara negara yakni pemerintah. Keterbatasan dan kemampuan yang pada masa sekarang menunjukan perhatian terhadap mereka belum terlaksana dengan baik. Kecilnya atau kurang keberpihakan pemerintah terhadap kelas bawah telah menyebabkan jumlah masyarakat miskin dan pengangguran menjadi sulit tertekan (terkurangi angka kemiskinan dan pengangguran).

Inilah yang menyebabkan termarginalkan nya masyakarat miskin dari hegemoni masyarakat mapan, yang kemudian berujung pada ketidakberdayaan masyarakat miskin untuk keluar dari kemelut yang melilitnya hingga kemudian beranggapan bahwa kemiskinan merupakan takdir sosial yang harus diterima dengan sabar dan pasrah. Padahal Allah tidak merubah nasib suatu kaum kecuali kaum itu yang mau merubahnya sendiri. Ayat ini menekanka pada sebuah perubahan dan perubahan itu dapat dilakukan melalui beberapa cara diantaranya yaitu dengan pendidikan. Karena pendidikan adalah usaha sadar terencana untuk mewujudkan suasana belajar dan proses pembelajaran agar peserta didik secara aktif mengembangkan potensi dirinya untuk memiliki kekuatan spiritual keagamaan, pengendalian diri, kepribadian, kecerdasan, akhlak mulia, serta keterampilan yang diperlukan dirinya, masyarakat bangsa dan Negara. Karena pendidikan mampu memainkan peranan yang sangat urgen maka dapat dikatakan bahwa pendidikan merupakan hak azasi manusia yang amat fundamental. Melalui pendidikan, anak dibentuk menjadi manusia seutuhnya, serta dengan berpendidikan tentu akan memahami hakekat dirinya, hakekat kehidupannya, hakekat bermasyarakat, beragama dan bernegara. Karena merupakan hak azasi maka hak pendidikan adalah harapan bagi anak-anak sebagai generasi harapan bangsa. Anak dilahirkan dengan hak hidup dan seiring itu memiliki pula hak untuk memperoleh pendidikan serta hak lainnya yang melekat pada diri anak.

Melihat kondisi seperti itu, maka kemudian yang memainkan peran penting untuk meminimalisir kondisi anak-anak yang tidak mampu melanjutkan pendidikan adalah panti asuhan-panti asuhan yang menampung sekaligus membiayai pendidikan bagi anak-anak tersebut, yang umumnya dari keluarga miskin dan tidak mampu. Lembaga panti asuhan merupakan alternatif yang memberikan jalan keluar dari dilema tersebut. Oleh karena anak ditampung dan ditanggung seluruh kebutuhan hidupnya oleh panti.

$$
\text { Panti asuhan At-Taqwa }
$$

Muhammadiyah Nagari III Koto merupakan salah satu panti asuhan yang terdaftar di Dinas Sosial dan Tenaga Kerja kabupaten Tanah Datar dengan jumlah anak asuh sebanyak 56 orang dengan jumlah pengasuh sebayak 3orang, merupakan asset berharga dalam membina kehidupan yang mengarah kepada pola pendidikan yang berorientasi kepada lifeskill yang di dasarkan kepadakeleluasa dalam mengatur waktu dan mengkonsentrasikan diri dalam kegiatan pendidikannya, tanpa harus bekerja membantu meringankan kebutuhan ekonomi keluarga.

Dari pengamatan yang dilakukan, ternyata panti asuhan At-Taqwa telah mempunyai lahan sendiri dengan luas tanah $20 \times 20 \mathrm{M} 2$ dan tetlah mempunyai usaha ekonomi dalam bentuk waserda dan beberapa buah mesin jahit namun belum terkelola dengan baik dikarenakan 
kekurang dana dan Sumber daya manusia untuk mengelola kegiatan dimaksud, serta upaya memberdayakan penghuninya dalam meningkatkan etos kerja melalui pelatihan keterampilan, latihan penanaman etos kerja untuk mengembangkan potensi mereka.

Pendirian lembaga panti asuhan yang memiliki fungsi strategis untuk pengembangan sumber daya manusia khususnya anak-anak dari keluarga miskin menjadi satu alternatif yang tepat. Panti asuhan mengambil alih fungsi keluarga untuk memenuhi kebutuhan seorang anak dalam menyongsong masa depannya. Dipanti asuhan anak memperoleh pelayanan yang banyak dalam memenuhi kebutuhan makan, pakaian, tempat tinggal,pendidikan, keterampilan kerja dan sebagainya. Pola pembinaan yang mengarah kepada pendidikan yang berbasis lifeskill.

Bertitik tolak dari latar belakang diatas, dan hasil dari permasalahan yang telah penulis teliti, maka penulis tertarik untuk turut aktif menyumbangkan pikiran atau ide dalam usaha pencapaian cita - cita khususnya dalam hal "Mencerdaskan Kehidupan Anak Bangsa" melalui media pendidikan. Penulis akan mencoba merancang program yang diberi nama "Program Pengembangan Potensi dan Pemberdayaan melalui Pendidikan Life Skill,"

Fokus penelitian ini adalah menyangkut Program Pengembangan Potensi dan Pemberdayaan melalui Pendidikan Life Skill di panti asuhan Attaqwa Muhammadiyah kenagarian III koto Kec. Rambatan Kabupaten Tanah Datar.

Rumusan masalah penelitian ini adalah : Bagaimana Life Skill di panti asuhan at-taqwa muhammadiyah kenagarian III koto Kec. Rambatan Kabupaten Tanah Datar.

Panti Asuhan adalah rumah atau tempat untuk memelihara dan merawat anak yatim, yatim piatu dan sebagainya (Casmini, 2007:826). Departemen Sosial Republik Indonesia (2007:4) menjelaskan bahwa : "Panti asuhan adalah suatu lembaga usaha kesejahteraan sosial yang mempunyai tanggung jawab untuk memberikan pelayanan kesejahteraan sosial kepada anak terlantar dengan melaksanakan penyantunan dan pengentasan anak terlantar, memberikan pelayanan pengganti fisik, mental dan sosial pada anak asuh, sehingga memperoleh kesempatan yang luas, tepat dan memadai bagi perkembangan kepribadiannya sesuai dengan yang diharapkan sebagai bagian dari generasi penerus cita-cita bangsa dan sebagai insan yang akan turut serta aktif didalam bidang pembangunan nasional".

Adapun ciri-ciri anak terlantar adalah: Pertama, kurang kasih sayang dan bimbingan dari orang tua; kedua, lingkungan keluarga kurang membantu perkembangannya, ketiga, kurang pendidikan dan pengetahuan; keempat kurang bermain; kelima, kurang adanya kepastian tentang hari esok dan lain-lain (Departement Sosia Republik Indonesia, 2007: 111).

Menurut Musdalifah, definisi dari Panti Asuhan adalah: "Panti asuhan dapat diartikan sebagai suatu lembaga untuk mengasuh anak-anak, menjaga dan memberikan bimbingan dari pimpinan kepada anak dengan tujuan agar mereka dapat menjadi manusia dewasa yang cakap dan berguna serta bertanggung jawab atas dirinya dan terhadap masyarakat kelak di kemudian hari. Panti asuhan dapat pula dikatakan atau berfungsi sebagai pengganti keluarga dan pimpinan panti asuhan sebagai pengganti orang tua; sehubungan dengan orang tua anak tidak dapat berfungsi sebagaimana mestinya dalam mendidik dan mengasuh anaknya" (Musdalifah, 2007: 1). 


\section{KAJIAN TEORITIS}

\section{Program Kegiatan Lifee Skiil}

a. Tujuan Desain Program

Adapun tujuan desain program ini diantaranya:

1) Membantu meningkatkan prestasi anak asuh tidak hanya dari sisi akademis tetapi juga non-akademis.

2) Memberi bekal bagi para anak asuh dengan pendidikan dan keterampilan informal untuk melengkapi pendidikan formal mereka dengan harapan agar kehidupan mereka akan menjadi lebih baik di masa yang akan datang.

3) Dapat meningkatkan manajemen panti asuhan dalam hal memberdayakan sumber daya manusia.

4) Dapat mengembangkan potensi potensi yang dimiliki oleh seluruh anak asuh.

5) Anak asuh mampu menghasilkan karya dari hasil potensi yang dimiliki.

b. Tahap-Tahap Pemberdayaan Panti Asuhan

Proses pemberdayaan panti asuhan terkait erat dengan faktor internal dan eksternal. Tanpa mengecilkan arti dan peranan salah satu faktor, sebenarnya kedua faktor tersebut saling berkontribusi dan mempengaruhi secara sinergis dan dinamis. Faktor internal sangat penting sebagai salah satu wujud self-organizing dari masyarakat namun kita juga perlu memberikan perhatian pada faktor eksternalnya. Tahapan pelaksanaan pemberdayaan Panti asuhan akan dimulai dari dari proses seleksi lokasi sampai dengan pemandirian panti asuhan. Secara rinci masing-masing tahap tersebut adalah sebagai berikut:

Tahap 1. Seleksi Lokasi/Wilayah

Seleksi kegiatan pengembangan lifeskill panti asuhan At-Taqwa Muhammadiyah dilakukan sesuai dengan kriteria yang disepakati oleh pengurus, pihak-pihak terkait dan masyarakat. Penetapan kriteria penting agar tujuan tercapai serta sebaik mungkin.

Tahap 2. Sosialisasi Pemberdayaan

Kegiatan ini untuk menciptakan komunikasi serta dialog dengan pengurus dan penghuni panti. Sosialisasi membantu untuk meningkatkan pengertian pengurus dan penghuni panti dan pihak terkait tentang program.

Tahap 3. Proses Pelaksanaan

Maksud pemberdayaan masyarakat panti asuhan adalah meningkatkan kemampuan dan kemandirian penghuni panti asuhan dalam meningkatkan ketrampilan (tujuan umum). Dalam proses tersebut melakukan hal-hal berikut:

a) Mengidentifikasi dan mengkaji permasalahan, potensinya serta peluang, Tahap ini sering dikenal dengan "kajian keadaan pedesaan partisipatif" atau sering dikenal dengan Participatory Rural Appraisal (PRA). PRA adalah suatu pendekatan yang memanfaatkan macam-macam teknik visualisasi (misalnya gambar, tabel dan bentuk/diagram) untuk proses analisa keadaan. Kegiatan ini dimaksudkan agar penghuni panti asuhan mampu dan percaya diri dalam mengidentifikasi serta menganalisa kedaannya, baik potensi maupun permasalahannya. Pada tahap ini diharapkan dapat diperoleh gambaran mengenai aspek sosial, ekonomi dan kelembagaan. Tahapan dalam proses kajian meliputi: (1) persiapan panti asuhan (2) persiapan dalam tim (kesepakatan teknik PRA, alat dan bahan, pembagian peran dan tanggungjawab), (3) pelaksanaan kajian keadaan: kegiatan PRA dan (4) pembahasan hasil dan penyusunan rencana tindak lanjut.

b) Menyusun rencana kegiatan, berdasarkan hasil kajian. 
Setelah teridentifikasi segala potensi dan permasalahan panti Asuhan, langkah selanjutnya adalah memfokuskan kegiatan pada penghuni panti asuhan yang benar-benar tertarik untuk melakukan kegiatan bersama. Pembentukan kelompok berdasar kemauan penghuni panti asuhan. Tahapan penyusunan dan pelaksanaan rencana kelompok:

1). Memprioritaskan dan menganalisa masalah-masalah hasil PRA lebih rinci, 2). Identifikasi alternatif pemecahan masalah terbaik, 3). Identifikasi sumberdaya yang tersedia untuk pemecahan masalah, 4). Pengembangan rencana kegiatan serta pelaksanaannya

c) Menerapkan rencana kegiatan kelompok

Rencana yang telah disusun bersama dengan dukungan fasilitasi dari pendamping selanjutnya diimplementasikan dalam kegiatan yang konkrit dengan tetap memperhatikan realisasi dan rencana awal. Pemantauan pelaksanaan dan kemajuan kegiatan menjadi perhatian semua pihak, selain itu juga dilakukan perbaikan jika diperlukan.

c. Memantau proses dan hasil kegiatan secara terus menerus

Tahap 4. Pemandirian Penghuni Panti Asuhan

Berpegang pada prinsip pemberdayaan masyarakat bertujuan untuk memandirikan masyarakat dan meningkatkan taraf hidupnya, maka arah pendampingan kelompok adalah mempersiapkan masyarakat agar benarbenar mampu mengelola sendiri kegiatnnya.

Unsur - unsur yang terlibat dalam pelaksanaan program ini, diantaranya sebagai berikut:

1. Anak Asuh
- Menjadi objek dalam pelaksanaan program pogram.

- Mengikuti seluruh agenda kegiatan untuk menemukan dan mengembangkan potensi diri.

2. Pembimbing/pengasuh

- Bertanggung jawab atas program kegiatan.

- Membimbing anak asuh di setiap agenda program kegiatan.

3. Tenaga Profesional

- Menjadi Pemateri/Trainer Motivator di beberapa program kegiatan.

4. Panti Asuhan

Materi Program

Adapun materi yang akan disajikan diantaranya sebagai berikut:

a. Achievement Motivation

b. Cara Membangkitkan Raksasa Dalam Diri Kita "Potensi Diri"

c. Cara Mengembangkan Potensi Diri

d. Materi tentang Penyuluhan keProfesi-an

Sebagai lembaga yang mewadahi seluruh program kegiatan

\section{KESIMPULAN}

Program Kegiatan yang dilaksanakan di Panti Asuhan At-Taqwa III Koto Rambatan meliputi lingkup pengasuh fisik, intelektual, spiritual, mental, keterampilan, khusus dibidang pengembangan Ketrampilan yang didasarkan pada program life skill, dengan memanfaatkan potensi dan sumber daya yang ada. Secara umum perhatian pemerintah baik pemerintah pusat maupun daerah sangatlah tinggi, sehingga yang diharapkan dari perhatian tersebut adalah menjalankan instruksi melalui "eksekusi" dari Pihak Panti Asuhan. Sumber daya alam yang tersedia di Panti Asuhan At-taqwa ini sangat mendukung kegiatan yang akan dilaksanakan melalui kegitan lafe skill, 
terutama dalam bidang pertanian dan peternakan. Program pengembangan life skill ini berorientasi kepada Program Pengembangan, Tujuan Desain Program, Tahap-Tahap Pemberdayaan Panti Asuhan (Tahap 1. Seleksi Lokasi/Wilayah, Tahap 2. Sosialisasi Pemberdayaan, Tahap 3. Proses Pelaksanaan, Tahap 4. Pemandirian Penghuni Panti Asuhan), Analisis Kebutuhan (Need Analisys) Program, Analisis SWOT, Materi Program, Strategi Layanan, Pelaksana, Alokasi Waktu dan Tempat dan Evaluasi Program

\section{DAFTAR PUSTAKA}

Nurihsan, Achmad Juntika. 2009. Strategi Layanan Bimbingan dan Konseling. Bandung: PT Refika Aditama, 2009)

Jahari, Jaja. 2008. Manajemen Sumber Daya Manusia. Bandung: Prosfect

Hasibuan, Malayu. 2007. Manajemen. Jakarta: PT Bumi Aksara

Siswanto. 2009. Pengantar Manajemen. Jakarta: PT Bumi Akasara

Nurihsan, Achmad Juntika. 2009. Bimbingan dan Konseling dalam Berbagai Latar Kehidupan. Bandung: PT Refika Aditama

Prayitno, H. dkk. 2004. Dasar - Dasar Bimbingan dan Konseling. Jakarta: PT Rineka Cipta

Corey, Gerald. 2009. Teori dan Praktek Konseling dan Psikoterapi. Bandung: Refika Aditama

http://www.pembelajar.com/limakekuatan-untuk-optimalisasipengembangan- potensi-diri

Bartle, Phil, 2003, Key Words C of Community Development, Empowerment, Participation: http://www.scn.org/ip/cds/cmp/keyc.htm).
CERD, 2004, Community Empowerment for Rural Development, http://www.cerd.or.id

Cook, James B, 1994, Community Development Theory, Community Development Publication MP568, Dept. of Community Development, University of Missouri-Columbia).

Delivery, 2004a, Pemberdayaan Masyarakat,

http://www.deliveri.org/guidelines/policy/ pg_3/pg_3_summaryi.htm 